Studies in African Linguistics

Volume 34, Number 2, 2005

\title{
INFORMATION STRUCTURING IN AKAN QUESTION-WORD FRONTING AND FOCUS CONSTRUCTIONS*
}

\author{
Charles Marfo and Adams Bodomo \\ University of Hong Kong
}

\begin{abstract}
Wh-question fronting and focus constructions in Akan have three structural characteristics in common: constituent fronting, introduction of a clitic morpheme after the fronted constituent, and pronoun resumption in a canonical clause position. In comparing these constructions to each other and to related canonical constructions, one is confronted with the question whether the same discourse-contextual information is consistently expressed in both constructions. Using the framework of Lexical-Functional Grammar, we show that both whquestion fronting and focus constructions share representations in the constituent and functional structure. Considering the individual discourse-contextual information expressed in wh-question fronting and focus constructions, as compared to the discourse-contextual information expressed in the respective in situ and canonical clause counterparts, however, we show that a variance is drawn between them in the information structure. In a further constraint-based analysis, Optimality-Theoretic LFG is used to clarify the proposals made.
\end{abstract}

\section{Introduction.}

In this paper, we discuss $w h$-question fronting and (contrastive) focus constructions (formally noted as marked sentence-types) and other facts that are related to

\footnotetext{
* This paper has benefited from comments and discussions with a number of people at different fora. We would like to thank participants at the LFG2004 conference held in Christchurch, New Zealand, especially Tracy Holloway King and Miriam Butt. We are also very grateful to two anonymous reviewers and the editor of this volume, David Odden, for raising many issues that have led to substantial revisions of parts of the paper.
} 
them in Akan, a Kwa language spoken in Ghana and some parts of Côte d'Ivoire. Three features characterize $w h$-question fronting and focus constructions in Akan: fronting of a constituent, introduction of a clitic morpheme after the fronted constituent, and pronoun resumption in a canonical clausal position. In comparing the two constructions to each other and to related non-extracting constructions, the question that one is confronted with is whether the same discourse-contextual information is realized in both constructions. In other words, as compared to related non-extracting constructions, does the resulting phrase structure configuration bring about semantic contrast in both constructions or not? This has been an internal controversy in Akan; specifically, compare Saah (1988) to Boadi (1990).

Using the framework of Lexical-Functional Grammar (LFG: Kaplan \& Bresnan 1982, Bresnan 2001, Dalrymple 2001), we explore the similarities and differences between $w h$-question fronting and focus constructions. In this paper we show that in the constituent (c-) structure and the functional (f-) structure, both wh-question fronting and focus constructions essentially share common representations. However, considering the individual discourse-contextual information that is expressed in wh-question fronting and focus constructions, as compared to the discourse-contextual information expressed in the respective in situ and canonical clause counterparts, we show that a variance is drawn between them in the information (i-) structure, which is accessible to the semantic (s-) structure (King 1997, Butt \& King 1998). In LFG, c-structure, f-structure, and istructure respectively model the categorical representation, the grammatical functions, and the discourse-contextual information aspects of the grammar (e.g., see (28)). The LFG account in this paper is novel and, with it, the separate semantic content of Q-word fronting and focus constructions can be explicitly presented through an (attribute value matrix (AVM)-based) i-structure. In a further constraint-based analysis, Optimality-Theoretic LFG (OT-LFG: Bresnan 2000, Kuhn 2001 ) is used to clarify and strengthen our suggestions.

The rest of the paper is organized as follows: in section 2, we give a descriptive account of $w h$-question constructions in Akan, including its constituent in situ and constituent fronting occurrences. The (contrastive) focus construction in Akan is then described in section 3. In sections 4 and 5, we explain how the two constructions are similar to, or different from, each other and throw light on the intricacies involved in their constructions within LFG. With insights from OT-LFG, section 6 illuminates the discussions in sections 4 and 5. Section 7 provides the conclusion to our observations and analyses. 


\section{Wh-Question Constructions.}

A wh-question construction in Akan is primarily identified by any of the interrogative phrases or pronouns in (1). Following Boadi (1990), we refer to the interrogative pronouns in (1) as question words or question phrases (hereafter, Qwords/Q-phrases). As discussed in sections 2.1 and 2.2, each of the Q-words can remain in situ in a canonical clause or fronted in an extra-sentential clause.

(1) hwán / hwáánóm

sén

á! déń / (sé) déćń /ấd čń (ńtí)

غ̀hé(é! fá)

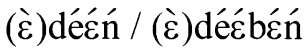

bréćbén / dàbéń

$\mathrm{NP}+$ bén
'Who / which people'

'How much, how many or what'

'Why / for what reason'

'Where'

'What'

'When'

'Which (of that item)'

2.1 Q-word in situ. The Q-words are substitutes for the various syntactic categories, particularly the argument functions. Therefore, as illustrated in (2b) and (2c) for the subject and the object respectively, these Q-words can remain in situ in a canonical clause; i.e., as substitutes for the constituents they question. When the verb is questioned in the in situ representation, as shown in (2c), it is replaced by another verb, $y \varepsilon$, literally meaning 'do.' In addition, the Q-word occurs in the final position.
a. Kùśí rè-sèré àbòfŕá nó
'Kusi is laughing at the child.'
Kusi Prog-laugh child DEF

b. Hwán rè-sèré àbòfrá nó

'Who is laughing at the child?'

Who Prog-laugh child DEF

$\begin{array}{ll}\text { c. Kùsí rè-sèré } & h w a ́ n \\ \text { Kusi Prog-laugh } & \text { who }\end{array} \quad$ 'Kusi is laughing at whom?'

d. Kùsí rè-yé àbòfrá nó déźn 'What is Kusi doing to the child?' Kusi Prog-do child DeF what

The c- and f-structure instantiations of the Q-word in situ construction in (2c) are shown in (3) below. The illustration in (3) also shows how c-structure maps to f- 
structure through the Structure-Function Mapping theory (Bresnan 2001, Dalrymple 2001, Falk 2001).

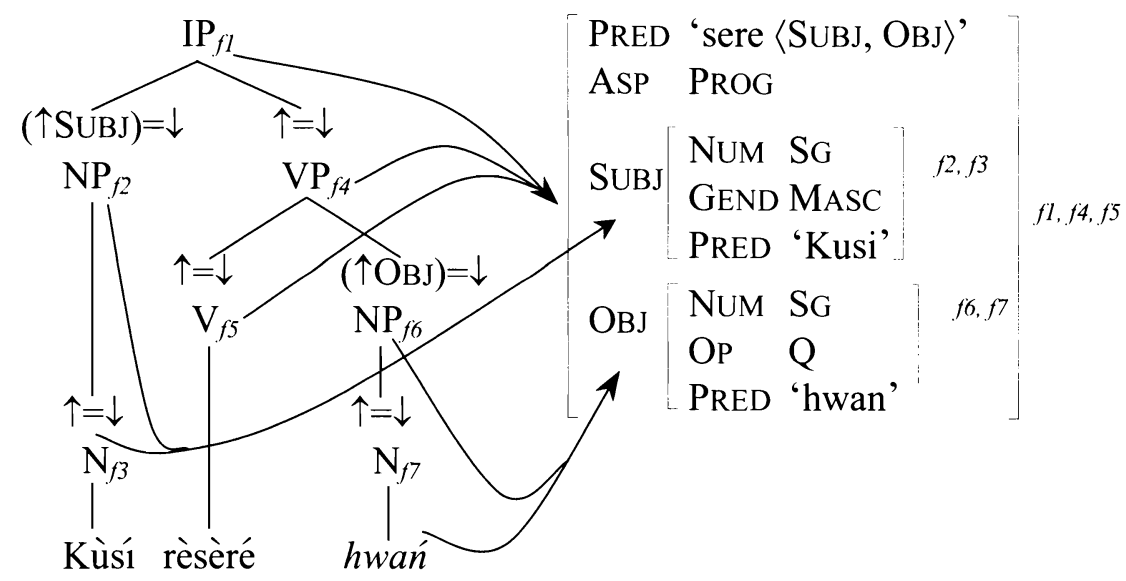

2.2 Q-word fronting. Besides the in situ representation of the wh-construction in Akan, with which the canonical phrase structure is maintained, there is another option of representation. This option involves the dislocation of the Q-word. Qword dislocation in Akan refers to the fronting of the Q-word (hence, Q-word fronting) in an extra-sentential construction. A clitic morpheme, nà, referred to as a focus marker (FOC) (Boadi 1974, 1990, Saah 1988), is also introduced at the right edge of the fronted Q-word. In other words, as illustrated in (4), an obvious phrase structure variation is realized where the Q-word appears in some position that is above the canonical clause.
(4)
$\begin{array}{rll}\text { a. [IP Kùsí rè-sèré } & \text { hwáń } \\ \text { Kusi } & \text { ProG-laugh } & \text { who }\end{array}$
'Kusi is laughing at whom?'

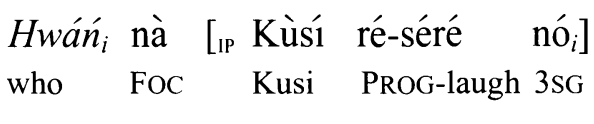
b. [IP Kòfi bé-'dúá dééń] 'Kofi will sow what?'
Kofi FuT-sow what

Dééń nà [ip Kòfí bé-'dúa ]

'What will Kofi sow?' what Foc Kofi FuT-sow 
In a bid to enforce an argument that Q-word fronting in Akan encodes emphatic information, as against the information expressed in a related in situ construction, Saah (1988: 19-20) observes with two examples, slightly modified in (5), 'that some Q-word in situ constructions related to greetings are canonically fixed in phrase structure (see (5a)). Thus, according to him, a corresponding Qword fronting option (see $(5 b))$ is ungrammatical.

a. Q-word in situ

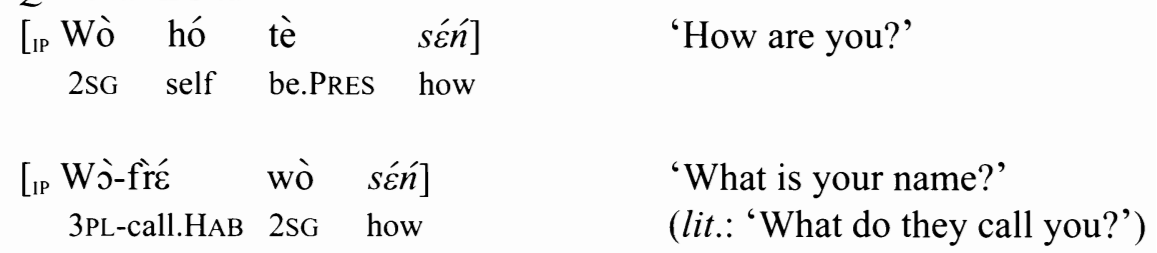

b. Q-word fronting

Sćn nà [ip wò hó té $(\varepsilon)$ ] 'How are you?'

how FOC 2SG self be.PrES

Sén nà [IP wò-f'ŕé wó $\quad$ 'What is your name?'

how FoC 3SG-call.HAB 2SG (lit.: 'What do they call you?')

Perhaps Saah's observation is true in other dialects of Akan. ${ }^{2}$ In Asante-Twi, however, fronting of greetings related Q-words is attested although it is a fact that it is not often done, as indicated in the grammatical constructions in (5b).

Saah (1988) also notes that where a Q-phrase is functioning as an adverbial of reason, it must be fronted obligatorily, as shown in (6a). According to him, the construction is ungrammatical where the Q-word remains in situ, as also shown in (6b). While being cautious about the supposed semantic difference between Qword/phrase in situ and Q-word/phrase fronting, he further suggests that the Qphrase needs to be at a stressed or emphatic position, hence the fronting; specifically, the specifier position of some projected pragmatic/discourse function. As

1 They are a little modified in the sense that we have used a different Akan text - i.e., the use of séń 'how' (in Asante-Twi), instead of déń in Saah's example.

${ }^{2}$ Akan is composed of several dialects. The prominent ones are Asante-Twi, Fante, and Akuapim-Twi. It seems to us that Saah (1988) was referring to Fante, considering his selection of Akan texts (e.g., the use of dén in Fante instead of sén in Asante-Twi). However, according to our observations, even in Fante, fronting of Q-words is generally acceptable. 
will be reiterated in section 5, we claim that a fronted Q-word does not invoke any further emphasis than what it inherently does at an in situ position in Akan (from Saah, 1988: 20).
a. Déèn àdé ńtí nà Kwàdwó bò-ò Á!má what thing because Foc Kwadwo hit-PST Ama 'For what reason/why did Kwadwo hit Ama?'

b. *Kwàdwó bò-j̀ Á!má dés̀ǹ àdé ńtí Kwadwo hit-Pst Ama what thing because 'For what reason/why did Kwadwo hit Ama?'

Indeed, it is true that (6b) is ungrammatical, as Saah rightly notes. However, the ungrammaticality is only due to the fact that the whole interrogative phrase (Qphrase), déżn àdé ńtí, asking for the reason behind the agent's (Kwadwo) action, is incomplete in the present position. The complete Q-phrase should be introduced by the complementizer (COMPL), sé, and read as sé dés̀n àdé ńtí. The complementizer is optional when the Q-word/phrase is fronted and it is actually related to $n^{\prime} t$ in the phrasal form, $s \varepsilon^{\prime} \ldots n^{\prime} t i^{\prime}$ 'because'. Observe in (7a) below, the alternative to $(6 \mathrm{~b})$, that the same Q-word in situ construction is grammatical with the complementizer as part of the Q-phrase. As has been noted earlier, Qwords/Q-phrases are only substitutes for canonical clause-internal constituents. So, the Q-phrase in (7a) actually replaces a phrase (of reason), like the one in (7b), which also has to be introduced by the COMPL. Otherwise, as also shown in $(7 \mathrm{c})$, the construction is ungrammatical.

(7) a. Kwàdwó bò-ò Á'má sé déc̀n àdé ńtí
Kwadwo hit-PAST Ama Compl what thing because
'For what reason/why did Kwadwo hit Ama?'

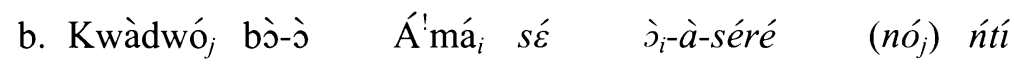

Kwadwo hit-PAST Ama COMPL 2SG-PRF-laugh 3SG because

'Kwadwo hit Ama because she has laughed (at him).'

c. *Kwàdwó ${ }_{j}$ bò-ò $A^{\prime} \mathfrak{m a ́}_{i} \grave{o}_{i}$-à-séré $\quad\left(n o_{j}\right) \quad n$ ntí Kwadwo hit-PST Ama 3SG-PRF-laugh 3SG because 'Kwadwo hit Ama because she has laughed (at him).' 
In addition, as we have suggested and will be discussed in detail in section 5 , the in situ construction in (7a) conveys the same discourse-contextual information that is expressed in the case of Q-phrase fronting construction in (6a). In other words, no semantic contrast obtains between (6a) and (7a).

\section{Focus Construction.}

A focus construction in Akan has a "point of prominence" within it (Boadi 1974) where contrastive information (of exclusivity) is intentionally placed for the purpose of emphasis. A constituent is contrastively focused in Akan when it is fronted in its extra-sentential projection of focus phrase (FOCP). The (fronted) constituent in focus is also immediately followed by the FoC, nà. Specifically, the FOC appears at the head position of the projected FOCP, as shown in (8). Also, observe in (8b) that when the sentential head is rather the constituent in focus, the same form of the verb-stem remains in situ. This is unlike the case of a questioned sentential head where $y \varepsilon$ is, instead, introduced in the canonical base position; see $(2 \mathrm{~d})$.
a. Kòfí rè-bòá Á!má
Kofi ProG-help Ama
'Kofi is helping Ama.'
b. [FocP Bòá ${ }_{i}$ nà [ip Kòfí ré-bóá ${ }_{i}$ Ámá]] help FoC Kofi ProG-help Ama
'It is help (that) Kofi is helping Ama.'
c. [FocP Á!má ${ }_{i}$ nà [IP Kòfí ré-bóá nó $\left.{ }_{i}\right]$ Ama FoC Kofi PROG-help 3SG
'It is Ama (that) Kofi is helping.'

Boadi (1974: 7) explains that, in focus constructions, the FOC has the function of narrowing down the referential range of its host, the focus constituent. The function of the FOC in focus constructions, therefore, is a semantic one. That is, it has discourse information alteration significance and, for that matter, it induces semantic contrast. As will become evident, clear semantic contrast is realized between a focus construction and its canonical clause counterpart.

Boadi (1974) notes that dèz, which occurs in the same syntactic position as $n a ̀$, also plays the role of a focus marker; for instance, $A^{\prime}{ }^{\prime} a_{i}$ dèz Kòf rébóa nó 
'as for Ama, Kofi is helping her' (cf. (8c)). As he finally asserts, however, let us note that dè $\grave{\varepsilon}$ does not define the concept of contrastive information in definite terms. Unlike nà, it does not induce an exclusive focus on a fronted constituent. The non-exclusivity of $d \grave{e} \dot{\varepsilon}$-focus construction is clearer in terms of contrastive account of focus. Supposing a statement is made with regards to an event, but a constituent in that statement (e.g., the subject or the object) is contrary to the truth of the event, in the correction of the statement by focus, the $n \grave{a}$-focus construction gives the appropriate contrastive account. For instance, observe in (9) below that, in giving a contrastive object to the one in the declarative statement, cohesion (indicated by a continuous arrow) attains between the declarative statement and the $n a$-focus construction in (9b). On the other hand, we realize that the dè -focus construction in (9c) does not logically/coherently follow from the declarative statement. This buttresses the point that $d \grave{e} \bar{\varepsilon}$ does not have the same focus marking function as nà. In other words, it does not induce an exclusive focus.
a. Kòf́1 rè-bòá Yàw
Kofi Prog-help Yaw
'Kofi is helping Yaw.'

b. Dààbí! Á!má nà Kơfí ré-bóá nó no! Ama FoC Kofi Prog-help 3SG

'No! It is Ama that Kofi is helping (her).'

c. Dààbí! Á!má dèc̀ Kòfí rè-bòá nó no! Ama Foc Kofi PRog-help 3sG

'No! As for Ama, Kofi is helping her.'

Also, unlike nà, dè̀ cannot come after a fronted Q-word, and thus using dè̀ in ${ }^{*} H w a n_{i}$ dè̀ Kòfí rébóá nó ${ }_{i}$ is ungrammatical. Therefore, aside from the fact that we do not consider dèz as a true Foc, it also falls outside the scope of this paper.

Indeed, there are other ways of putting a constituent in focus (specifically, in prominence) that do not involve constituent fronting: for instance, the use of intonation, as shown in (10a), and the use of inherently focus-marked words like 'only', as shown in (10b). However, it is important to note that a constituent that has been focused in situ (as shown in (10a-b)) could still be fronted for the purpose of contrastive information realization in Akan. As shown in (10c), for example, the subject is fronted along with the inherently focus-marked word, nkkóáa (cf. (10b)). 


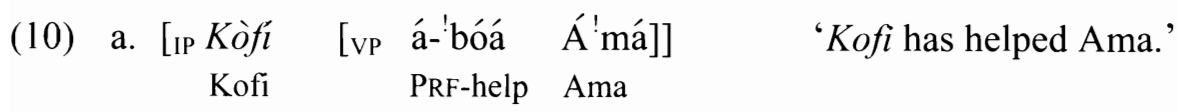

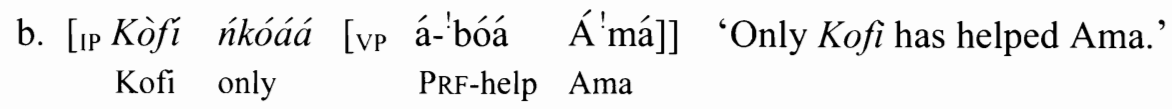

c. [FocP Kòfí ńkóáá nà [IP ó-[vP á-bóá Á!má]]] Kofi only FOC 3SG- PRF-help Ama 'It is only Kofi who has helped Ama.'

In the light of the realization of focus examplified in (10c), we particularly draw attention to the fact that, in this paper, we are concentrating on focus marking that involves not only prominence, but new/contrastive information as well. That is to say, contrastive focus is only realized through constituent fronting in Akan.

A constituent cannot be contrastively focused in situ in Akan because the FoC cannot be used in the canonical clause. As noted earlier, the FOC is only introduced at the head position of the extra-sentential projected FOCP. This explains the ungrammaticality of the constructions in (11); i.e., the introduction of the FOC in the canonical clause is unattested.
(11) a. *[ip Kòfí ré-bóá Á!má nà] 'It is Ama (that) Kofi is helping.' Kofi Prog-help Ama FoC
b. *[ip Kòfí nà ré-bóá Á 'má] 'It is Kofi who is helping Ama.' Kofi FoC Prog-help Ama

It is important to note that the focus construction is related to the Q-word fronting construction in Akan with regards to constituent fronting and the use of the FOC at the head position of a projected functional phrase. Besides these two phrase structure facts, another connection between the two constructions is that a focus construction is more or less an answer to a Q-word fronting construction in a question-answer pair (Boadi 1974). Therefore, as exemplified with the subject in (12) below, the answer constituent to the Q-word in the Q-word fronting construction corresponds to the constituent in focus in the focus construction. Perhaps, this correspondence contributed to Saah's (1988) suggestion that a fronted Q-word is more emphatic, as compared to an in situ counterpart. 


\section{(12) Question}

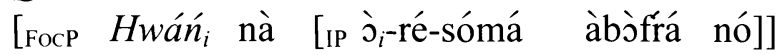
who FOC 3SG-ProG-send child DEF

'Who is sending the child?'

Answer/Focus

[FocP Kùsí $i_{i}$ nà [IP ว̀-ré-sómá àbòfrá nó]]

Kusi FoC 3SG-Prog-send child DEF

'It is Kusi who is sending the child.'

\section{More on Q-Word Fronting and Focus Constructions.}

We have noted constituent fronting in Q-word and focus constructions in Akan. Current research in LFG (e.g., Berman 1997, Bresnan 2000, 2001) describes constructions exhibiting this phenomenon as forms with discourse function (DF), projected to absorb the fronted constituent. Observe in (12) above that, in light of the structural hierarchy at c-structure, the fronted constituents in Spec-FocP show an iconic structural precedence and dominance over other constituents in both constructions. We have also observed that FOC appears at the head position of the projected DF (FOCP) in both constructions, as in (12) and other data already given.

One other feature, which both Q-word fronting and focus constructions exhibit and is worth noting in the light of LFG, is the presence of a resumptive pronoun (henceforth, RPro) in the canonical clause position of a fronted constituent (i.e., the Spec-FocP constituent). This RPro agrees in number and in person with the Spec-FocP constituent, as can be seen in (13-15) below. Observe in (13) that, with their appearance in Spec-FoCP, the plural subjects (in focus or in question) are replaced in the canonical position (i.e., Spec-IP) with the third person plural pronoun, wó( $)$. The singular subjects (in focus or in question) in (14) and (15) are also replaced in the canonical position with the third person singular pronouns; i.e., j-(nó) for an animate subject and $\grave{\varepsilon}$-(nó) for inanimate subject. The RPros then refer back to the Spec-FocP constituents, hence the co-indexing of Spec-FocP and Spec-IP. 
(13) [FocP Mmááa nà [IP wò̀-hwé m̀mòfráa] female.PL FOC 3PL-look.HAB child.PL

'It is females who take care of children.'

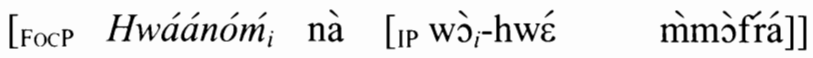
who.PL FOC 3PL-look.HAB child.PL

'Which people take care of children?'

(14) a. [FocP כ̇báá ${ }_{i}$ nà [IP $\grave{j}_{i}$-hwé m̀mòfráa] female.SG FoC 3sG-look.HAB child.PL

'It is a female who takes care of children.'

b. [FocP $H w a ́ n n_{i}$ nà [IP $\grave{j}_{i}$-hwé m̀mòfráa] who FOC 3sG-look.HAB child.PL

'Who takes care of children?'
$\begin{array}{llll}\text { (15) [FocP } & \dot{\mathcal{E}} \text { tòa } & \text { nà } & {\left[\grave{\text { IP }}_{i} \text {-bó-í1] }\right.} \\ \text { bottle } & \text { FoC } & \text { it-break-PAST }\end{array} \quad$ 'It is a bottle that broke.'
[FocP Dééńn
what FOC it-break-PAST

It is important to note that the RPros are essentially pronouns of Akan. As presented in (16) below, therefore, we call attention to the fact that an RPro is not just an agreement marker, but a pronoun (in position) that has to agree in person and number with a fronted argument function. Note also that only the nonbracketed syllables of the pronouns are normally said in the appropriate argument positions, as observed in (13-15) above.

(16) Pronouns of Akan

\begin{tabular}{|c|c|c|c|c|}
\hline \multirow[b]{2}{*}{ Person } & \multicolumn{2}{|c|}{ Subject } & \multicolumn{2}{|c|}{ Object } \\
\hline & Singular & Plural & Singular & Plural \\
\hline $\begin{array}{l}1^{\text {st }} \\
2^{\text {nd }} \\
3^{\text {rd }}\end{array}$ & $\begin{array}{l}\text { mé 'I' } \\
\text { wó 'you' } \\
j(\text { nó) 'she/he'; }\end{array}$ & $\begin{array}{l}y \dot{\varepsilon}(n) \text { 'we' } \\
m o ́ \text { 'you' } \\
\text { wó(n) 'they' }\end{array}$ & $\begin{array}{l}m e ̀ \text { 'me' } \\
\text { wò 'you' } \\
\text { (j)nó 'her/him'; }\end{array}$ & $\begin{array}{l}\text { yéń 'us' } \\
\text { mò 'you' } \\
\text { wòn 'them' }\end{array}$ \\
\hline
\end{tabular}


Going back to the data in (13-15), observe that the RPros are in the third person. This does not mean that an RPro should always be in the third person. The RPros are in the third person in (13-15) because third person pronouns are the right (pronominal) substitutes for full noun argument functions. As shown in (17a), where the argument function in focus is a first person singular pronoun for instance, its RPro should also be in the first person singular - i.e., the same pronoun. Otherwise, as also shown in (17b), the construction is ungrammatical. The focus construction in (17a), however, shares a common corresponding Q-word fronting construction with (14a); i.e., $H w a n_{n}{ }_{i} n a ̀ \grave{j}_{i}-h w \varepsilon$ mìmòfra 'who takes care of children?' in (14b).

(17) a. [FocP $M e_{i} \quad$ nà [IP $m \grave{e}_{i}$-hwé mì̀̀frá] $]$

'It is me who takes care of children.'

b. *[FocP $M e_{i}$ nà [IP $\grave{j}_{i}$-hwé mòmòfrá] $]$

1sG FoC 3sG-look.HAB child.PL

'It is I who takes care of children.'

As noted by Saah (1988: 24) referring to Stewart (1963: 149), unlike in the subject position, the occurrence of RPro is restricted in the object position (and other post-verbal environments). This restriction has to do with the feature specification of animacy; i.e., [ \pm animate]. Specifically, if a fronted object or object-inquestion is animate ([+animate]), its canonical base position is filled with the appropriate RPro, as shown in (18a) and (19a). Lack of an RPro for a fronted animate object or object-in-question renders a construction ungrammatical, as shown in $(18 \mathrm{c})$ and $(19 \mathrm{c})$.

(18) Focus:

a. [FocP Àtó $o_{i}$ nà [IP j̀báá nó [vp ré-bóá [NP nó $\left.\left.\left._{i}\right]\right]\right]$ Ato FoC lady Def Prog-help 3SG 'It is Ato that the lady is helping.'

b. [FocP غ̇móó ${ }_{i}$ nà [IP j̀báá nó [ [vP nóá [ [NP $\left.\left.\left.\left.\varnothing_{i}\right]\right]\right]\right]$ rice FoC lady DEF cook.HAB $e$

'It is rice (that) the lady cooks.' 


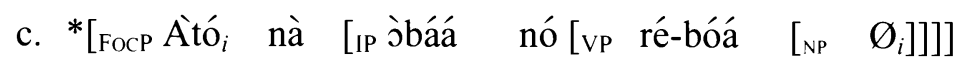
Ato FoC lady DEF PROG-help $e$

'It is Ato that the lady is helping.'

d. *[FocP Èmóó $_{i}$ nà [IP j̀báá nó [VP nóá [ [NP nó $\left.\left.\left.{ }_{i}\right]\right]\right]$ rice FoC lady DEF cook.HAB 3SG

'It is rice (that) the lady cooks.'

(19) Q-word fronting:

a. [FocP $\mathrm{Hwán}_{i}$ nà [IP j̀báá nó [VP ré-bóá [NP nó $\left.\left.\left.{ }_{i}\right]\right]\right]$ who FOC lady DEF PROG-help 3SG

'Who is the lady helping?'

b. [FocP Dééńn ${ }_{i}$ nà [IP jobáa nó [VP nóá $\left.\left.\left[\begin{array}{ll}\mathrm{NP} & \emptyset_{i}\end{array}\right]\right]\right]$ what FOC lady DEF cook.HAB $e$

'What does the lady cook?'

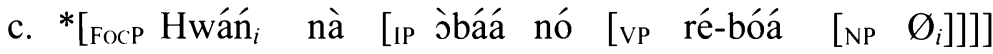
Who FOC lady DEF PROG-help $e$ 'Who is the lady helping?'

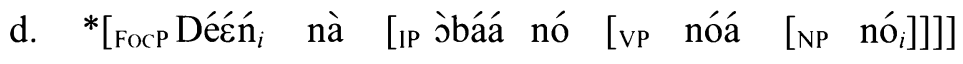
rice FOC lady DEF cook.HAB 3SG

'What does the lady cook?'

Conversely, where the fronted object or object-in-question is inanimate ([-animate]), the RPro is covertly represented, as in (18b) and (19b). As shown in (18d) and (19d), an overt RPro for a fronted inanimate object or object-inquestion renders a construction ungrammatical. Saah (1992: 221) refers to the lack of overt RPro in the inanimate situation as an "empty category" $(E C)$ situation in Akan.

Regarding the animacy of an object and whether or not it is human (i.e., [fhuman]), as shown in (20a) and (20b) respectively, it is important to note that both [+animate; +human] and [+animate; -human] objects have the same RPro in the canonical position. However, as shown in (20c), an RPro could be optional in the case of [+animate; -human] objects. 


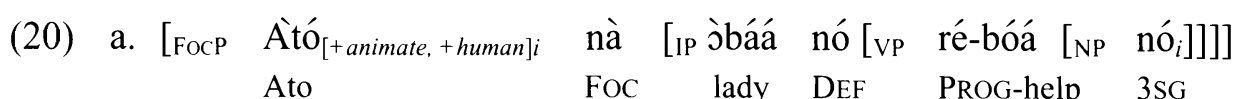
'It is Ato that the lady is helping.'

b. [FocP A`kókó ${ }_{[+ \text {animate, }- \text { human }] i}$ nà [IP joáá nó [VP ré-yéǹ [NP nó $\left.\left.\left.{ }_{i}\right]\right]\right]$ fowl.SG FoC lady DEF PROG-help 3SG

'It is a fowl that the lady is rearing.'

c. [FocP Àkókó ${ }_{[+ \text {animate, }- \text { human]i }}$ nà [IP jobáá nó [vP ré-yéń $\left[\begin{array}{ll}{ }_{N P} & \left.\left.\left.\emptyset_{i}\right]\right]\right]\end{array}\right]$ fowl.SG FOC lady DEF PROG-help 3SG

'It is a fowl that the lady is rearing.'

In the wh-construction, while hwán replaces [+animate; +human] objects (see (19a)), [+animate; -human] objects are replaced by déźn 'what' (or dés̀n àbóá / àbóá béń 'what animal'); e.g., Déèn àbóá nà jbáá nó réyćñ nó 'what animal is the lady rearing?' (cf. (19a)).

Where there is a need to show in the c-/f-structures that the inanimate object is covertly represented, some versions of LFG account for the phenomenon through the Principle for Identifying Gaps (Bresnan 2001: 181) provided in (21). The principle is necessary in the linking up of such an $E C$ to the Spec-DF (FOCP) constituent, thus enabling the integration of Spec-DF constituent (a nonargument) in the argument structure in f-structure.

\section{(21) Principle for Identifying Gaps:}

Associate $\mathrm{XP} \rightarrow e$ with $((x \uparrow) \mathrm{DF})=\uparrow$

Through the Principle for Identifying Gaps, the violation of the Economy of Expression principle (e.g., Bresnan 2001) by having an EC in the c-structure is bypassed. The Economy of Expression principle states that all syntactic phrase structure nodes are optional and use of any of them is prohibited unless independent principles demand it.

Perhaps, the animacy restriction on objects, and not on subjects, also emphasizes the Subject Condition (SC) which LFG stipulates. SC requires every predicate to have a subject, but not necessarily an object. Based on the inspiration of SC, we posit the condition, Strict Phonetic Subject (SPS), stated in (22), for extra-sentential clauses in Akan (in this paper, Q-word fronting and focus constructions). 
(22) Strict Phonetic Subject:

Every predicator in the embedded clause of an extra-sentential clause must have a phonetic subject.

SPS is motivated against a possible proposal that a fronted subject (in a focus or wh-construction) does not need RPro in the canonical clause, since it is still the most prominent in the relational hierarchy and is the default DF. In this sense, SPS is not merely a stipulation. In fact, it has to be satisfied in other extrasentential constructions in Akan as well; e.g., topic constructions and relative clauses. SPS explains the grammaticality and ungrammaticality of the focus constructions in (23b) and (23c) respectively.
a. [IP Kùsí rè-sòmá mé]
Kusi Prog-send 1SG
'Kusi is sending me.'

b. [FocP Kùsíi nà [IP ว̀-ré-sómá mé]]

Kusi FOC 3SG-PROG-send 1SG

'It is Kusi who is sending me.'

c. *[FocP Kùsíi $i_{i}$ nà [IP $\emptyset_{i}$-ré-sómá mé]]

Kusi Foc _-Prog-send 1sG

'It is Kusi who is sending me.'

\section{Distinction: Discourse-Contextual Information.}

So far, it has been made clear that both Q-word fronting and focus constructions essentially share a common marked (or extra-sentential) phrase structure configuration; i.e., $\left[{ }_{F O C P} X P\right.$ nà $\left.\left[{ }_{I P} \ldots\right]\right]$. However, considering the individual discoursecontextual information that is realized in the s-structure of each of them, through the i-structure (Vallduví 1992, Lambrecht 1994), as compared to the discoursecontextual information expressed in the s-structure of the respective in situ and canonical clause counterparts, we explain in this section that semantic contrast is clearly evident in focus constructions.

In exploring the different types of discourse-contextual information that obtain in Q-word fronting and focus constructions, let us assume that the semantic content in each of the constructions particularly has to do with (or is tied to) the obligatory occurrence of the FOC, besides the constituent fronting. With this as- 
sumption, as already noted in section 3, we suggest that, unlike in focus constructions, the occurrence of the FOC in Q-word fronting constructions does not invoke any information of semantic significance in the discourse other than what obtains in the discourse of related Q-word in situ counterparts. In other words, in Akan, Q-word fronting does not alter the s-structure of the interrogative in any way.

We do not dispute the fact that, in some languages, Q-word fronting may invoke contrastive information (as against the discourse-contextual information expressed in a related in situ construction). Mutaka \& Tamanji (2000: 221) note that in Bafut, a Grassfields Bantu language spoken in Cameroon, a Q-word fronting construction encodes more emphasis than its in situ counterpart, although both of them ask virtually the same question. The study clams that a Q-word fronting construction expresses a high degree of concern on the part of the speaker. Thus, as shown in (24) for example from Mutaka \& Tamanji (2000: 221 ), the speaker is insisting to know the specific "thing" (the object) that Suh killed in (24c), but the speaker shows no such insistence in (24b).

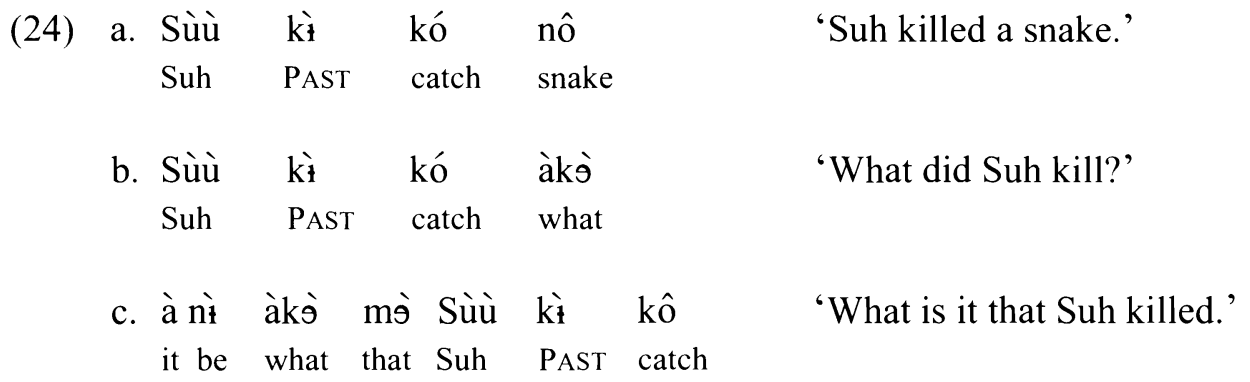

Perhaps, this "speaker-intention" argument could be made in Akan as well. However, we contend that it has no semantic relevance in the discourse. That is, semantic contrast does not obtain between a Q-word fronting construction and its in situ counterpart in Akan as it does between a focus construction and a related canonical construction.

Boadi (1990: 78) suggests that the lack of semantic contrast in a Q-word fronting construction in Akan, as compared to a related Q-word in situ construction, is due to the semantic fact that Q-words are actually inherently focusmarked. Accordingly, they do not need any special reference. We further claim in this paper that a Q-word holds the core of the information profile of a construction within which it appears (i.e., the expression of interrogative). Thus, a Q-word does not need any further semantic buffer, in this case the FOC, to complete what it already inherently establishes. Sabel (2000: 430), citing Hovarth (1986: 118), 
explains that focus is a syntactic feature that is assigned to a non-echo wh-phrase. This strengthens our position that Q-words are inherently focus-marked; so, they do not need to be assigned further focus. As Boadi (1990) notes, Q-word fronting is only an alternative, optional representation.

A test for ascertaining that Q-words are inherently focus-marked is that, following a previous discourse, only a Q-word could be used to represent the whole of a construction within which it occurs. Accordingly, in (25) below, the whole of (25b) can be replaced by (25c), drawing directly from (25a). In other words, $(25 \mathrm{c})$ is a follow up to $(25 \mathrm{a})$, just as $(25 \mathrm{~b})$ is. On the contrary, observe that (25e) cannot be a follow up to (25a) and so, it cannot represent the whole of (25d). That is, as a non-Q-word, the word in (25e), Kofi, which is also the SpecFOCP constituent in (25d), is not inherently focus-marked. So, it can only be contrastively focused in the focus-presupposition structure, as shown in (25d).
a. $K o ̛ f$
bé-'dúá
àbá nó
'Kofi will sow the seed.'
Kofi FUT-sow seed DET

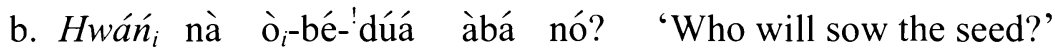
who FOC 3SG-FUT-sow seed DET

c. Hwáń?

who

'Who?' (appropriate alternative to b.)

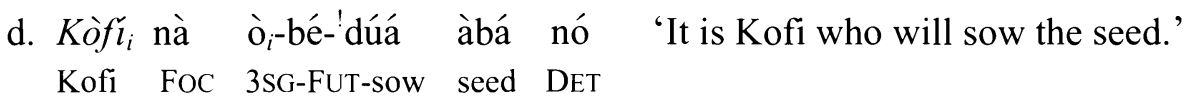

e. $K o ̀ f \imath$

'Kofi' (not an appropriate alternative to $\mathrm{d}$.)

As noted earlier, contrary to the stance taken in this paper, Saah (1988: 19) claims that, as a motivation for the constituent left-periphery dislocation, extrasentential clause-initial Q-word occurrence is more emphatic, as compared to the in situ counterpart. The question, however, is to what extent is a fronted Q-word more emphatic? With regards to discourse-contextual information, what can we draw from its i-structure (which is accessible to the s-structure, as noted earlier) that is different from what is obtained in the i-structure of a related Q-word in situ construction? Seemingly emphasized as a fronted Q-word in Akan is, it is actually vacuous in terms of semantic contrast to a related Q-word in situ construction. As 
explained in section 2.1 (see and contrast (6a) and (7a)), Q-word fronting (with the employment of FOC) induces nothing more into its i-structure other than what is in the i-structure of the in situ construction (i.e., the general interrogative expression of the Q-words).

On the other hand, the identification of a semantic contrast in the istructure of a focus (of extraction) construction, as compared to that of a related canonical construction, is indisputable and readily perceptible. Contrastive information is attained in focus construction, particularly relating to the constituent in focus. In this case, among all the constituents in the construction, the one in focus is highlighted as the point of contrastive discourse information (of exclusivity) in the construction; hence, its constitution as the "point of prominence" (Boadi 1974). For instance, the focus construction in (25d), Kôfl nà òbé! dúá àbá nó 'it is Kofi who will sow the seed', is interpreted as 'it is Kofi and only Kofi (within a discourse-relevant subset of individuals) who will sow the seed', and not just as 'Kofi will sow the seed'. With the latter interpretation, none of the constituents is identified as prominent (or new) information. Accordingly, other people besides Kofi might sow the seed as well; hence, the contrast between it and the former interpretation of focus. Kiss (1995) puts the interpretation of focus as follows: "the focus operator serves to express identification" (Kiss 1995: 212). In the focus construction in $(25 \mathrm{~d})$, for instance, constituent fronting and the use of the FOC identify $K o f i$, and only $K o f i$, as the one who is sowing the seed.

We realize that a focus construction differs in semantic content from a related canonical clause when we put both constructions in yes-no question. In answering the question, with the focus construction, the constituent in focus alone could be retrieved into the answer, as can be observed in (26a). ${ }^{3}$ On the other hand, with the canonical clause, the whole construction has to be repeated in the answer, as shown in (26d). The retrieval of any particular constituent into the answer results in question-answer incoherence, as shown in $(26 \mathrm{e})$. This is because, unlike in focus constructions, no particular constituent is put in (contrastive) focus in the canonical clause.

${ }^{3}$ In answering (26a), the whole focus construction could also be retrieved; i.e., Àáné, $\grave{A} d \hat{u}_{i}$ nà

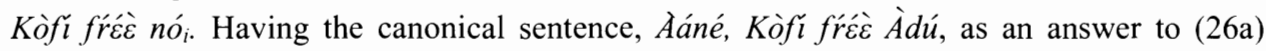
sounds funny. 


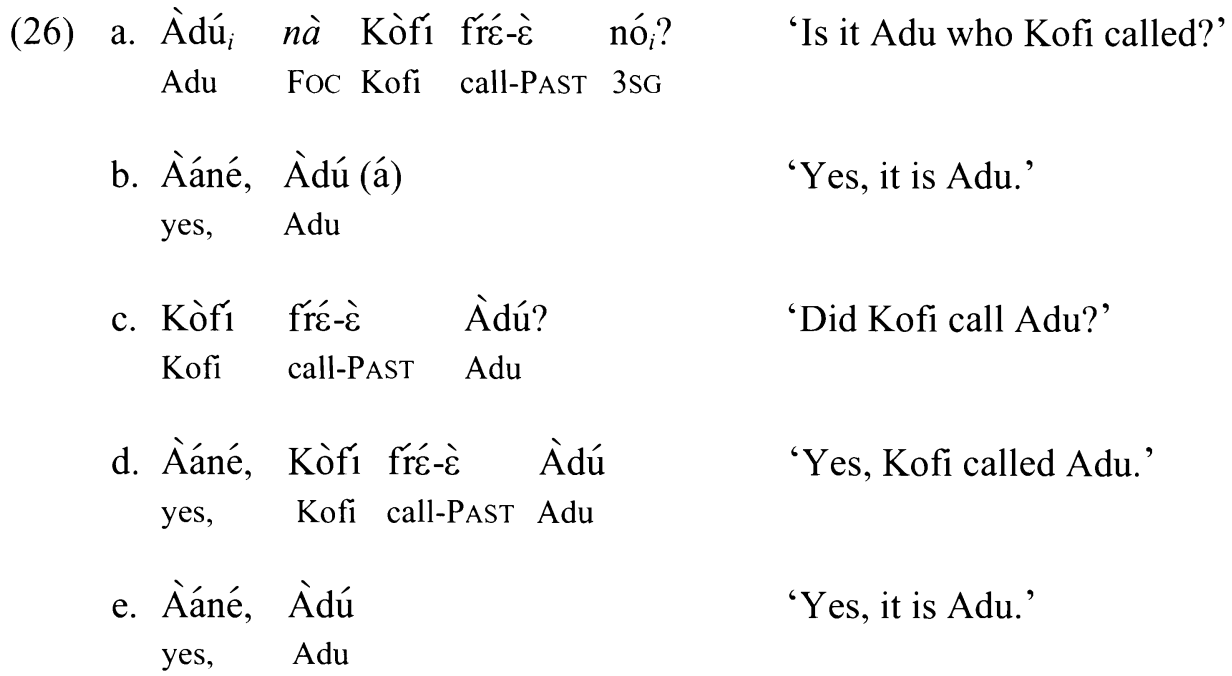

Despite the semantic distinction made between Q-word fronting and focus constructions in relation to their non-extracting clause counterparts, it is important to note that "focus-presupposition" information structure is reflected in both constructions, which goes to prove that both Q-word and focus express prominent new information. With the manifestation of "focus-presupposition" structure in Q-word fronting constructions, one cannot deny the fact that they involve some sort of focusing. Kroeger (2004: 139) notes that "the question word bears a pragmatic focus, since it specifies the crucial piece of new information which is required; the rest of the question is part of presupposition". Sabel (2000: 430) also puts it this way: "the $w h$-phrase designates what is not presupposed as known". Now, since a Q-word constitutes a linguistic device for the identification of a specific piece of prominent new information, it should be recognized as prominent new information as well. As shown in (27) below, we observe that it is from the questioning in (27a) that Kusi realizes as prominent new information in (27b) and, for that matter, the focus.

(27) a. Question: Hwáńn nà ذ̀ -ré-sómá àbòfrá nó?
who FoC 3sG-ProG-send child DEF
'Who is sending the child?'

b. Focus: Kùsí $i_{i}$ nà òi-ré-sómá àbòfrá nó

Kusi FoC 3sG-ProG-send child DEF

'It is Kusi who is sending the child.' 
Following the feature-based i-structure (Choi 1999, 2001, Lee 2001), which we extend here to include Q-words, Q-words and focused constituents in Akan would therefore show identical information profiles on discourse NEW(ness) and Prom(inence), as shown in (28).

Information profile of gocus and Q-word

Focus $\left[\begin{array}{l}\text { NEW }+ \\ \text { PROM }+\end{array}\right] \quad$ Q-word $\left[\begin{array}{l}\text { NEW }+ \\ \text { PROM }+\end{array}\right]$

Going back to Q-word fronting and focus constructions in relation to their non-extracting clause counterparts, however, it has been noted that, unlike in Qword fronting constructions, the Foc has a semantic function in focus constructions; i.e., it alters the default discourse-contextual information of a related canonical clause. We refer to this semantic function of the FOC in focus constructions as discourse-contrast, since it results in contrastive information (of exclusivity; i.e., ' $X$ and only $X$ ') that characterizes focus constructions in Akan. Conversely, discourse-neutral (Lee 2001) is obtained with the occurrence of the FoC in Q-word fronting constructions, since the same discourse-contextual information expressed in related Q-word in situ constructions is expressed in them. It logically follows then that "Q-word fronting in Akan is only an optional representation" (Boadi 1990: 78) and the obligatory occurrence of the FOC with it is only a general syntactic restriction. In line with structural markedness, we refer to the FOC in Q-word fronting constructions as configurational focus, since its occurrence contributes to the marking of the whole phrase structure configuration. Recall that Q-word fronting and focus constructions are noted as marked sentence-types.

Having identified and explained the common information profile, defining pragmatic focus, of Q-words and focused constituents and their different semantic interpretations in a construction, we now present a common c-structure and individual $\mathrm{f}$ - and i-structures of the Q-word fronting and focus constructions in (29) below. In the individual i-structures in (29c) in particular, we show the different realizations of the common information profile (presented in (28)) in the interpretation of Q-word fronting and focus constructions relative to the discoursecontextual information that obtain in related non-extracting constructions - i.e., the realizations of discourse-neutral of Q-words and discourse-contrast of focus. 
(29) a. C-structure (for both Q-word fronting and focus constructions)

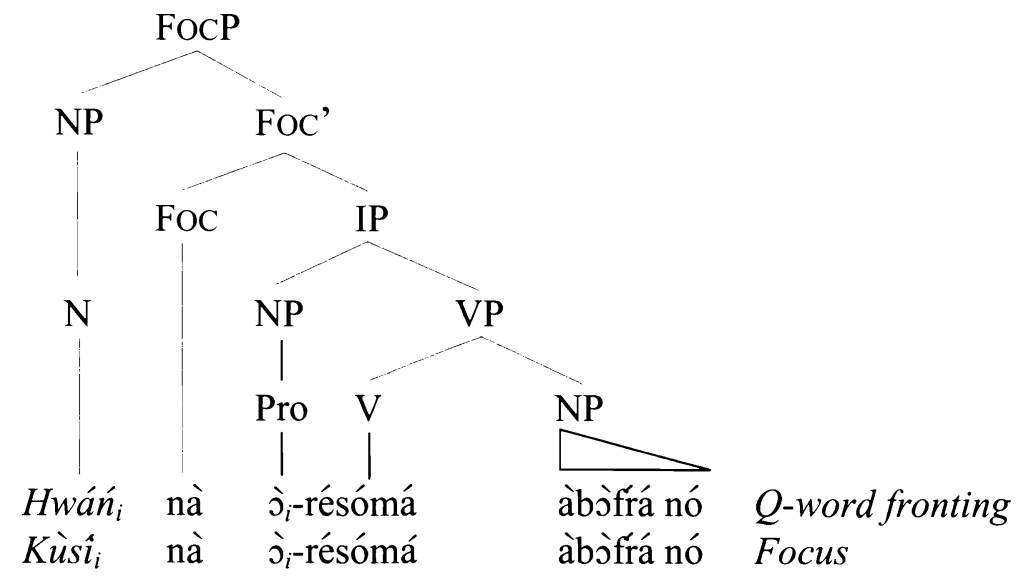

b. F-structures

Q-word fronting

\begin{tabular}{|c|c|}
\hline PRED & 'soma $\langle$ SUBJ, OBJ $\rangle$ \\
\hline ASP & PROG \\
\hline DF & \\
\hline SuRI & NuM SG \\
\hline SUBJ & PRED 'Pro' \\
\hline & NuM SG \\
\hline ОВЈ & $\mathrm{DEF}+$ \\
\hline & PRED 'abofra' \\
\hline
\end{tabular}

Focus

Pred 'soma $\langle$ SUbJ, OBJ $\rangle$
AsP ProG
DF
SUBJ $\left[\begin{array}{l}\text { NUM SG } \\ \text { PrEd 'Kusi' }\end{array}\right]$
OBJ $\left[\begin{array}{l}\text { NUM SG } \\ \text { DEF + } \\ \text { PrEd 'abofra' }\end{array}\right]$

c. I-structures

Q-word fronting

$\left[\begin{array}{c}\text { FocUS }\left[\begin{array}{l}\text { F-TYPE NEUTRAL } \\ \text { I-PRED 'Hwan' }\end{array}\right] \\ \text { BGD }\left[\begin{array}{l}\text { òrésòmá } \\ \text { àbòfrá nó }\end{array}\right]\end{array}\right]$

Focus

$\left[\begin{array}{ll}\text { Focus } & {\left[\begin{array}{l}\text { F-TyPe Contrastive } \\ \text { I-Pred 'Kusi' }\end{array}\right]} \\ \text { BGD }\left[\begin{array}{l}\text { òrésòmá } \\ \text { àbòfrá }\end{array}\right]\end{array}\right]$

We have already discussed how the common c-structure is realized in section 4. The argument functions subcategorized by the verb, sòmà, in both constructions are also encoded in the individual f-structures. Also encoded in the f- 
structures is the identification of the projected DF with an argument function, the subject. The individual semantic significance in the discourse of Q-word fronting and focus constructions is also given in the separate i-structures. Here, the focus type (F-TYPE) of the Q-word, hwán (noted as information predicate (I-PRED)) is given as neutral following FOC function as discourse-neutral in Q-word fronting construction, while that of the focused constituent, Kùsí, is given as contrastive following FOC function as discourse-contrast in focus constructions. The rest of both constructions are given as presupposition/background information (BGD). Istructure is observed here as distinct structure from the f-structure projected off the c-structure (King 1997, Butt \& King 1998). Recall that it is accessible to the s-structure for semantic interpretation.

Since Q-words have been noted as inherently focus-marked in Akan, finally, it is important to note that a Q-word fronting construction is distinguished from its in situ counterpart only on the basis of c-structure configurational markedness. As noted on several occasions, with respect to discourse-contextual information realization, both representations are essentially the same.

\section{Constraining the Constructions: OT-LFG.}

With a recast of LFG within Optimality Theory (OT-LFG) (Bresnan 2000, Choi 1999, Kuhn 2001), the common c-structure configuration of Q-word fronting and focus constructions is further established in this section. We also illustrate and constrain harmonic alignment (Aissen 1999, Bresnan 2000, Choi 2001, Lee 2001) between the common c-structure and the i-structure of a particular construction. Each of the parallel structures of LFG defines prominence in a hierarchical fashion. The matching of prominence definition in one structure to that in another structure constitutes a harmonic alignment.

6.1 Categorial representation. Two conflicting constraints readily come to mind concerning constituent fronting in Q-word fronting and focus constructions. These are OP-SPEC, motivated by the presence of a syntactic operator (Grimshaw 1997, Bresnan 2000, Kuhn 2001) and recast in expression as operator in specifier of functional projection, and *DISLOC, proposed in this paper on the inspiration of the economy principle and expressed as don't dislocate. As stated in (30), while OP-SPEC favors functional projection and the appearance of a constituent in question/focus in Spec-DF, *DISLOC stands to block such a categorial representation. For a Q-word fronting or focus construction word order to prevail, therefore, OPSPEC must crucially outrank *DISLOC. 
(30) OP-SPEC:

An operator (i.e., a constituent in focus/question) must be in the specifier position of its functional projection.

*DISLOC:

Don't dislocate; the canonical phrase structure must not be altered.

The other typological traits of Q-word fronting and focus constructions noted earlier also need to be recast and explained in terms of constraints, if alternative categorial representations are to be properly rejected. It has been noted that the projected phrase of the operator function has to be headed by the FoC, nà. Also noted is the fact that an argument function that appears at the specifier position of the projected functional phrase has to be replaced in the embedded canonical clause position by an RPro. The appropriate constraints we employ to demand these representations are OB-HD/fp (Bresnan 2000, Choi 2001, Kuhn 2001) and PARSE/gf, proposed here on the motivation of SPS; (see (22)). ${ }^{4}$ Respectively expressed as obligatory head and parse argument functions, OB-HD/fp and PARSE/gf are also stated in (31) below. In the constraint ranking, we assume a dominance of PARSE/gf between the two. However, both constraints should dominate *DISLOC and should be dominated by OP-SPEC (see Tableau I).

(31) $O B-H B / f p$ :

The head position of a functional projection must be filled.

PARSE/gf:

Left dislocated argument function should be phonetically represented in the canonical clause position.

The f-structure in (32), a merged f-structure of both constructions in (29), is employed as the working input. The attribute-value matrix (AVM) of the operation and other features underscored in the individual constructions are not indicated in the input f-structure of the two constructions, since they do not undermine the c-

${ }^{4}$ An alternative view is that SPS should be kept in the constraint formulation, but that would restrict pronoun resumption to only the subject position. That is, considering the fact that fronted/focused animate objects also have to be resumed, PARSE/gf better captures the phenomenon. 
structure configuration in any way. Tableau (I) also explains that, among the candidate set of (a), (b), (c), and (d), the optimal candidate is the one whose c-/fstructures best relate to this input. Both Q-word and focused constituents are represented in Spec-FocP as NP in the tableaux.

(32) Input f-structure: Hwán ${ }_{i} / \mathrm{Kùs}_{i}$ nà j̀-résómá àbj̀frá nó

$\left[\begin{array}{lll}\text { Pred } & \text { 'soma } & \langle\text { SUBJ, OBJ }\rangle \\ \text { ASP } & \text { ProG } & \\ \text { DF } & {[} & \\ \text { SUBJ } & \text { [PrED } & \text { 'Pro / Kusi' } \\ \text { OBJ } & \text { Pred } & \text { 'abofra' }\end{array}\right.$

(I)

\begin{tabular}{|c|c|c|c|c|c|c|}
\hline & & Matrix Q-word fronting/focus & $\begin{array}{l}u \\
\text { In } \\
2 \\
0 \\
1 \\
0 \\
0\end{array}$ & 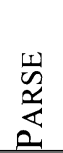 & $\begin{array}{l}\stackrel{0}{\underline{1}} \\
\stackrel{1}{0}\end{array}$ & 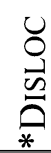 \\
\hline \multirow[t]{4}{*}{$\Phi$} & a. & $\left[\right.$ FocP $\mathrm{NP}_{i} n a ̀$ [IP $\left.\left.\operatorname{Pro}_{i}[\mathrm{VP} \mathrm{V} \mathrm{NP}]\right]\right]$ & & & & $*$ \\
\hline & b. & [IP NP [VP V NP]]] & $* ! *$ & & & \\
\hline & c. & {$\left[\mathrm{FOCP}_{\mathrm{PP}} \mathrm{NP}_{i}\left[\mathrm{IP}_{i} e_{i}[\mathrm{VP} \mathrm{V} \mathrm{NP}]\right]\right]$} & & $* !$ & & * \\
\hline & $\mathrm{d}$. & 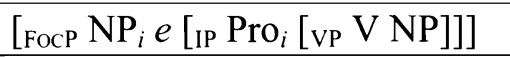 & & & $* !$ & * \\
\hline
\end{tabular}

In Tableau (I), candidate (a) outperforms the other candidates as follows: Candidate (b) is taken out (on two counts) for not having a functional projection, let alone a constituent in question/focus occurring in its specifier position. Candidate (c) is also ruled out on PARSE/gf for violating the requirement of having an RPro in place of the fronted argument function (in the present case, the subject function) in the embedded canonical clause. Candidate (d) is also taken out of consideration for its violation of $\mathrm{OB}-\mathrm{HB} / \mathrm{fp}$, which ensures functional projection headedness. Consequently, the grammatical c-/f-structure of candidate (a) prevails as the optimal candidate. Note that the input f-structure in (32) essentially doubles as fstructure of candidate (a).

6.2 Information correspondence: alignment. We have noted that Q-word fronting and focus constructions share a common information profile in the istructure as regards NEW and PROM. Choi (2001: 34) proposes i-/c-structure cor- 
respondence/alignment constraints based on NEW and PROM that yield informationally-motivated marked c-structure. Relevant among these constraints in the present cases of Q-word fronting and focus constructions are NEW-L and PROM-L recast in (33) below.

(33) NEW-L:

[+NEW] aligns left in the construction of occurrence.

PROM-L:

[+PROM] aligns left in the construction of occurrence.

Since both Q-word and constituent in focus are noted as '[+PROM]; [+NEw]' in the feature-based i-structure, and each of them sits at Spec-FOCP, at present the most prominent position in the structural hierarchy at c-structure, it is obvious that the i-/c-structure correspondence constraints in (33) will be satisfied in both constructions (see Tableau II). Comparing their individual discoursecontextual information to the information that obtains in their respective Q-word in situ construction and canonical clause counterparts, however, Q-word fronting and focus constructions have been set apart in the s-structure through the projected i-structure (see (29c)) as "discourse-neutral" and "discourse-contrast" respectively. These separate semantic orientations of Q-word fronting and focus are expressed in constraint terms in (34) below, following Choi's (2001) NEW-L and PROM-L proposals.

(34) NEUT-L:

[+NEUT] aligns left in the construction of occurrence.

CONST-L:

[+CONST $]$ aligns left in the construction of occurrence.

With the present constraints in the constraint set, Tableau II below show that CONST-L must crucially outrank NEUT-L where there is a need to establish i/c-structure harmonic alignment in a focus construction (i.e., a correspondence between a constituent in focus and the Spec-FocP position, as against harmonic alignment between a fronted Q-word and the Spec-FOCP position). Observe in the tableau that, unlike the ranking of CONST-L against NEUT-L, the ranking between CONST-L and New-L/PROM-L in the Tableau is hardly crucial and, for that matter, has little or no impact at all in the i-/c-structure correspondence. As noted earlier, 
this is because both fronted Q-word and focus constituent sit at Spec-FocP and specify for $[+\mathrm{NEW}] /[+\mathrm{PROM}]$.

\begin{tabular}{|c|c|c|c|c|c|}
\hline & {$\left[\right.$ FocP $\left.\mathrm{NP}_{i} n a \grave{a}\left[\mathrm{IPro}_{i}[\mathrm{VP} \mathrm{V} \mathrm{NP}]\right]\right]$} & $\begin{array}{l}\frac{1}{1} \\
3 \\
Z\end{array}$ & $\sum_{0}^{1}$ & $\begin{array}{l}\frac{1}{1} \\
\vdots \\
0 \\
0\end{array}$ & $\begin{array}{l}-1 \\
5 \\
\\
\end{array}$ \\
\hline a. & 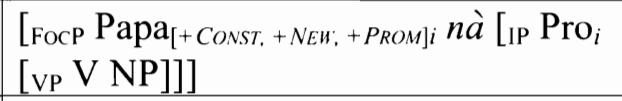 & & & & $*$ \\
\hline b. & $\begin{array}{l}{\left[\mathrm{FOCP}_{\mathrm{P}} \mathrm{HWan}_{i[+N E U T,+N E w,+P R O M] i} n \grave{a}\left[\mathrm{IP} \mathrm{Pro}_{i}\right.\right.} \\
[\mathrm{VP} \mathrm{V} \text { NP }]]]\end{array}$ & & & $* !$ & \\
\hline
\end{tabular}

It is important to note that CONST-L and NEUT-L are only necessary constraints motivated on individual semantic content to draw attention to the s-structure distinction between Q-word fronting and focus constructions. Thus, the fact that the focus construction outperforms the fronted Q-word construction in Tableau II does not mean that the Q-word fronting construction is ungrammatical. As has already been mentioned in previous sections, it only explains that, unlike in a focus construction, no semantic contrast is realized in the i-structure of a Q-word fronting construction, as compared to that of related in situ construction - i.e., the discourse-contextual information is not altered. Ranking NEUT-L over CONST-L will also select i-/c-structure correspondence in Q-word fronting construction.

\section{Conclusion.}

It has been shown in this paper that Q-word fronting (in wh-questions) and focus constructions in Akan essentially share the same phrase structure configuration, which involves constituent left dislocation, introduction of the focus marker (FOC), nà, and insertion of a resumptive pronoun (RPro) for a dislocated argument function. Further, it has also been illustrated, using the OT-LFG framework, that the same c-/f-structure constraints and their rankings essentially ensure the configuration of both constructions.

Through the attribute-value matrix (AVM)-based i-structure, however, we have drawn attention to the individual semantic content of Q-word fronting and focus constructions based on the individual discourse-contextual information that obtains in them in comparison to discourse-contextual information that obtains in 
respective in situ construction and canonical clause counterparts. It has been explained that the occurrence of the FOC, along with constituent left-periphery dislocation in a Q-word fronting construction does not result in semantic contrast because the discourse-contextual information expressed in it is the same that obtains in an in situ counterpart. On the other hand, constituent left-dislocation and the occurrence of the FOC in a focus construction do bring into play semantic contrast. In other words, a constituent is highlighted among others as an obvious point of contrastive information in the information profile of a focus construction. Using OT-LFG, we have stressed this semantic information distinction between the two constructions, which further shows the optimization of a particular i-/cstructure alignment in the grammar.

\section{REFERENCES}

Aissen, Judith. 1999. "Markedness and subject choice in Optimality Theory". Natural Language and Linguistics Theory 17: 673-711.

Berman, Judith. 1997. "Empty categories in LFG". On-line Proceedings of the LFG97 conference, University of California, San Diego, ed. by Miriam Butt \& Tracy Hollaway King. Stanford: CSLI Publications.

URL: http://csli-publications.stanford.edu/LFG/2/lfg97-toc.html.

Boadi, Lawrence A. 1974. "Focus-marking in Akan". Linguistics 140: 5-57.

Boadi, Lawrence A. 1990. "Questions in Akan". Frankfurter Afrikanistische Blätter 2: 70-92. 
Bresnan, Joan. 2000. "Optimal syntax". Optimality Theory: Phonology, Syntax and Acquisition, ed. by Joost Dekkers, Frank van der Leeuw \& Jeroen van de Weijer. Oxford: Oxford University Press. Pp. 334-385.

Bresnan, Joan. 2001. Lexical-Functional Syntax. Oxford: Blackwell.

Butt, Miriam \& Tracy Holloway King. 1998. "Interfacing phonology with LFG". On-line Proceedings of the LFG98 Conference, University of Queensland, Brisbane, ed. by Miriam Butt \& Tracy Holloway King. Stanford: CSLI Publications.

URL: http://csli-publications.stanford.edu/LFG/3/lfg98.html.

Choi, Hye-Won. 1999. Optimizing Structure in Context: Scrambling and Information Structure. Stanford, CA: CSLI Publication.

Choi, Hye-Won. 2001. "Resolution of mismatches". Formal and Empirical Issues in Optimality-Theoretic Syntax; Studies in Constraint-based Lexicalism 5, ed. by Peter Sells. Stanford, CA: CSLI Publications. Pp. 17-62.

Dalrymple, Mary. 2001. Lexical-Functional Grammar: Syntax and Semantics 34. New York: Academic Press.

Falk, Yehuda. 2001. Lexical-Functional Grammar: An Introduction to Constraint-Based Syntax. Stanford: CSLI Publications.

Grimshaw, Jane. 1997. "Projection, heads, and optimality". Linguistic Inquiry 28: $373-422$.

Horvath, Julia. 1986. FOCUS in the Theory of Grammar and the Syntax of Hungarian. Dordrecht: Foris.

Kaplan, Ronald M. \& Joan Bresnan. 1982. "Lexical-functional grammar: a formal system for grammatical representation". Formal Issues in LexicalFunctional Grammar, ed. by Mary Dalrymple et al., 1995. Stanford: CSLI Publications. Pp. 29-130. 
King, Tracy Holaway. 1997. "Focus domain and information-structure". On-line Proceedings of the LFG97 Conference, University of California, San Diego, ed. by Miriam Butt \& Tracy Holloway King. Stanford: CSLI Publications. URL: http://csli-publications.stanford.edu/LFG/2/lfg97-toc.html.

Kiss, Katalin É. 1995. "NP movement, operator movement, and scrambling in Hungarian". Discourse Configurational Languages, ed. by Katalin É. Kiss. Oxford Studies in Comparative Syntax, Oxford University Press. Pp. 207-243.

Kroeger, Paul R. 2004. Analyzing Syntax: a Lexical-Functional Approach. Cambridge University Press.

Kuhn, Jonas. 2001. "Generation and parsing in Optimality Theoretic syntax". Formal and Empirical Issues in Optimality-Theoretic Syntax: Studies in Constraint-Based Lexicalism 5, ed. by Peter Sells. Stanford: CSLI Publications. Pp. 313-366.

Lambrecht, Knud. 1994. Information Structure and Sentence Form. Cambridge: Cambridge University Press.

Lee, Hanjung. 2001. "Markedness and word order freezing". Formal and Empirical Issues in Optimality-Theoretic Syntax: Studies in Constraint-Based Lexicalism 5, ed. by Peter Sells. Stanford: CSLI Publications. Pp. 17-62.

Mutaka, Ngessimo N. \& P. Ngwe Tamanji. 2000. An Introduction to African Linguistics. Munich: Lincom Europa.

Saah, Kofi K. 1988. “Wh-questions in Akan”. Journal of West African Languages 18, 1: 17-28.

Saah, Kofi K. 1992. "Null object constructions in Akan". Proceedings of the Kwa Comparative Syntax Workshop. MIT Working Papers in Linguistics. Vol. 17: 219-44.

Sabel, Joachim. 2000. "Partial wh-movement and the typology of wh-questions". Wh-Scope Marking: Linguistik Aktuell/Linguistics Today 37, ed. by Uli Lutz, Gereon Muller \& Arnim von Stechow. Amsterdam: John Benjamins. Pp. 409476. 
Stewart, John M. 1963. "Some restrictions on the object in Twi". Journal of African Languages 2: 145-149.

Vallduví, Enric. 1992. The Informational Component. New York: Garland.

Department of Linguistics University of Hong Kong HKU-Main Building Pok Fu Lam Road Hong Kong, S.A.R China cmarfo@graduate.hku.hk abbodomo@hku.hk [received December 18, 2004 accepted September 9, 2005] 